\title{
The Transition of Universities from Face to Face teaching to Online Teaching: The Covid-19 Calamity
}

\author{
Natalia S. Intja, Martha Nahole \\ anreino@unam.na \\ University of Namibia, Rundu Campus, Windhoek 88, Namibia \\ University of Namibia, Rundu Campus, Windhoek 88, Namibia
}

\begin{abstract}
The covid-19 plague has brought about momentous challenges for the higher institutions of learning worldwide. A particular challenge has been the sudden and urgent need for previously face to face learning to move online. Online learning calls for a certain science of teaching, mostly redesigning the face to face curriculum to suit the online learning mode as well as ensuring that the latter provides a distinctive and comfortable learning space, with the help of digital technologies. This paper provides some possible insights into this online learning related to the science of teaching, with the aim of helping university lecturers with little or no experience with online teaching to navigate in these challenging times. The findings point at the design of learning activities and teaching methods with certain features at the university of Namibia's Rundu campus and the need for adapting assessment to the new learning requirements. Interviews were conducted to find discernments on how online teaching and learning may be directed during the pandemic. The inquiries were made through lecturers teaching Integrated and Media Technology and those teaching Educational Technology modules at the university of Namibia. Data were analysed thematically. All in all, the paper provides insights on how responding to the covid-19 predicament may subdue teaching and learning practices in the post-digital world.
\end{abstract}

Keywords: Online teaching; online learning; Higher institutions of learning; Science of teaching; Covid-19; Face to face teaching

\section{Introduction}

The exigent necessity to move online, triggered the recent Covid-19 pandemic (World Health Organisation, n.d) has supplemented to the stress and workloads experienced by university faculties and academic staffs who are already struggling to balance lecturing, researching and rendering community services and engagements, not to mention the work-life balance (Rapanta, Botturi, Goodyear, Guardia and Koole, 2020). Academic staff of all backgrounds and ages have had to prepare and deliver lectures inn the comfort of their homes, despite all the practical and technological challenges this entails and often without proper technical scaffolding (Hodges, Moore, Lockee, Trust and Bond, 2020). In addition, a significant impediment for university lecturers is that they lack the pedagogical content knowledge (PCK) needed for teaching online (Ching, Hsu and Baldwin, 2018) such PCK is an inclusion of using Panopto, Zoom, BigBlueButton, Podcast recorders, etc. to facilitate learning online. Paramount, the need to design lectures appropriate for online delivery. 
The present article focusses on the science of teaching aiming at helping university lecturers with little or no experience with online teaching to navigate in these challenging times. As recent studies have shown (Ocak, 2011; Ching et al, 2018) some of the challenges cited by the lecturers is the multifaceted nature of online planning, teaching and organisation. This calamity of Covid-19 has brought about many advices for lecturers (Bates, 2020) and the dominant advice is on the tools and materials that lecturers can use to substitute the face- to - face pedagogy. Methods of lecturing are provided but they are not explicit as when is each method best applicable. It is against this background that this paper sought to refine some online pedagogy guidance for lecturers amidst and post Covid-19.

\section{Literature Review}

Online learning is defined vastly by a plethora of researchers. This article has adopted the definition of (Bakia, Shear, Toyama and Lasseter, 2012) which refers to instructional environments supported by the internet. This learning umbrellas a variety of programs make use of the internet to provide access to learning materials and facilitate learning (Bakia et al, 2012). The rapid closing off of face to face learning in response to the Covid-19 pandemic since 2020 at the University of Namibia broke the bridge enabling greater comprehension among lecturers to know the difference between online teaching and any other modes of content delivery.

Post digital obtrude that online education has distorted boundaries between material, digital and human experience (Fawn, 2019). Anderson, Rourke, Garrison and Archer (2001) affirm that instructional design and organisation play an important role. Carr-Chellman (2016) assets that instructional design and learning design illuminate processes of suggested steps that lecturers can use to plan, implement and evaluate their instruction. Constructing on Bates (2019) assumptions, a good quality design has explicit and attainable learning objectives, carefully structured content, controlled workloads for faculties and students, integrated media, relevant student activities and assessments strongly tied to desired learning outcomes.

Moallem (1998) reference that expert lecturers in face to face mode of learning utilise ID and LD theories to execute decision making processes. Tennyson and Schott (2010) articulates that online learning is distinctive in nature whereby technologies are perceived to be the only means of teaching and the use of design processes is necessary. Regardless of the ID and LD theories, what is important in the end is that lecturers work towards designing conditions under which students have a better chance to learn (Parchoma, Koole, Morrison, Nelson and Dreaver-Chales (2019). Goodyear and Dimitriadis (2013) postulate that the perspective of design for learning is that lecturers act as both constructors and actors. To substantiate this, lecturers need to design lessons that they need to present to students according to the course outlines and be able to facilitate the online teaching and learning. It is worth noting that many online courses in the past were designed by learning design specialists and delivered by lecturers. In this era were Covid-19 is in our midst, instantaneous lecturers have been asked to become designers and tutors using tools which few have confidence in to use. This paper sheds light on pedagogical knowledge that novice online lecturers need in order to design and facilitate comprehensive lessons, activities and excel in this unacquainted space and use it even in the post Covid-19 era. The goal is to help university lecturers with little or no experience with online lecturing to navigate in these challenging times. 


\section{Methodology}

By employing qualitative modes of inquiry, this paper attempt to illuminate how online teaching and learning may be directed during the pandemic. Expert lecturers in this area were interviewed using semistructured interview guides which were sent to their e mail addresses for them to respond to them. The researcher adopted the qualitative approach because it produces detailed description of participants' feelings, opinions, experiences and interprets the meaning of their actions (Rahman, 2017), which is the core reason for this study. Moreover, this study is framed under the Community of Inquiry (CoI) model for online learning environments developed by Garrison, Anderson and Archer (2000) as cited in Picciano (2017). This model is based on the concept of three distinct presences: cognitive, social and teaching (see figure 1). It supports the design of online and blended courses as active learning environments depend on instructors and students sharing ideas, information and opinions. Of particular note is that presence is a social phenomenon and manifests itself through interactions among students and lecturers. It advocates students and lecturers to use discussion forums, blogs, wikis and video conferencing to mention a few.

\subsection{Theoretical Framework: Community of Inquiry (CoI) Model}

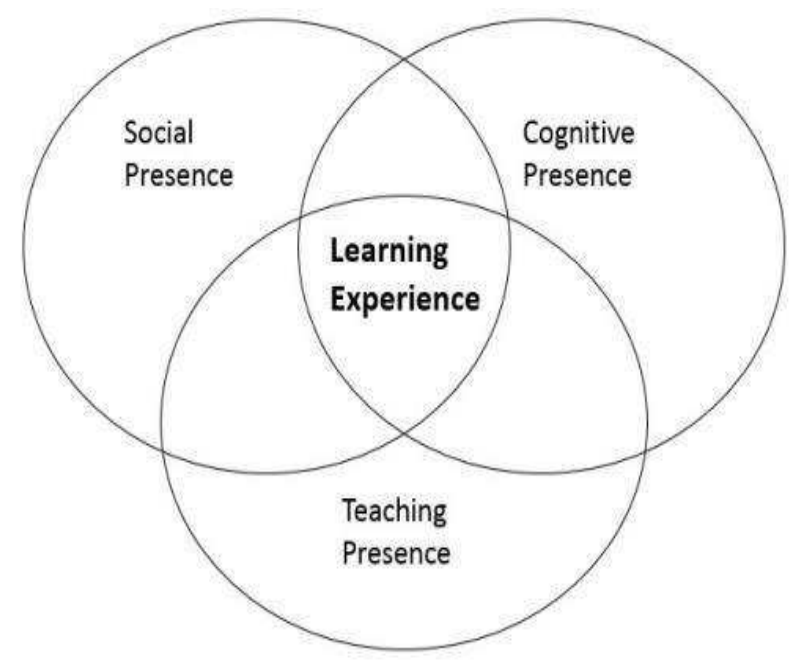

Figure 1 Community of Inquiry (CoI) model espoused from Garrison, Anderson and Archer (2000)

\section{The three interview questions are as follow:}

1. In what facets do you think online learning design and delivery is different than face-to-face teaching and learning?

2. What do you think makes online teaching and learning successful? 
3. What are some effective ways of monitoring students' engagement and learning during online courses? How can they inform assessment?

The following are the responses synthesised into themes deduced from the three interview questions.

\section{Theme 1: Online Learning Design and Delivery and Face to Face Teaching and Learning: Disparities}

Online learning is based more on either synchronous or asynchronous learning. While in asynchronous or asynchronous learning students are allowed to access materials, ask questions and practice their skills gained at any time that works for them, synchronous learning requires attendance at scheduled meetings or lectures. While this could be in person in a traditional lecture, in online setting it includes scheduled quizzes, tests chat room times for students to share ideas, Microsoft Teams video, livestreamed lectures via Zoom, etc. asynchronous learning uses recorded presentations, such as slide shows, emails, discussion boards, social media groups to allow lecturers and students to interact on their own schedules. Asynchronous learning is flexible which allows students to balance family, work and school. Moreover, the design of online learning is student centered. The lecturer facilitates the virtual classroom, while the students on when to submit assignments ensuring that its done before the due date and time. In face to face learning, students are expected to submit assignments to lecturers physically. Online learning allows more time for students and lecturers in thinking and responding as they craft their persona to edit with a special emphasis on what they wish to convey, which is not the case in face to face learning, as the questions posed requires to be responded to instantly before the lesson continues.

\section{Theme 2: Dynamics that enhance Online Teaching and Learning}

All interviewees are of the opinion that to ensure that online teaching and learning is successful in trying times, the design should be student-centered, the activities should be social and collaborated by peers. Substantively, the paper's framework advocate that online learning is a social phenomenon and it manifests itself through students and lecturer's interactions (Picciano, 2017). The lecturers should carefully think about what students will have to do to learn. Doing this will enable them to learn. Students can listen to podcasts, read texts or watch videos. Successful online learning entails not feeling alone and not forgetting that learning is social. We learn from others and with others, even if at a distance. From the lecturers' perspective, stimulating collaboration such as group assignments is key. Henceforth, the lecturer should execute excellent communication skills and active involvement of students. This implies clarity over expectations-explain to students what they need to do in the given assessments and the need to do it. Listening to their complaints about their challenges regarding online learning is part of good communication. Lecturers may also host a welcome forum which can help them get to know their students and help the class establish rapport. Course outlines and study guides can be send to students' prior the start date.

Theme 3: Effective ways of monitoring students' engagement and learning during online courses and how they may inform assessment

One way is controlling the data on students' activities in the Learning Management System. The lecturer can monitor students' engagement by looking at the frequency of posts on forums, accessing the course and contributions made at forums. When students are regularly participating in discussions and synchronous 
discussions, lecturers are helped to assess comprehension and performance and able to notice a student who is inactive.

\section{CONCLUSION}

This study was carried out a year after Covid-19 was declared a global pandemic and the university of Namibia had to adhere and observe the pandemic's protocols by moving all its courses online which were offered face to face. Due to the time constraints of carrying out research that is meaningful however rapid, the researcher opted for a heuristic research method of relying on experts for viewpoints. From the rationale above, the limitation of the study is the practicability of some of the dynamics of ensuring that online teaching and learning is successful. i.e. using the internet to teach via zoom, Microsoft teams videos, etc. because not all students have devices that can enable them to use zoom. Some might have the devices but lack the internet connectivity to attend lectures and do assessments on Moodle. Another limitation may be that the findings of this paper are arriving somewhat too late for the university lecturers to adopt as they might have been guided already on how to teach online during this crisis. Nevertheless, online teaching is an important component of professional preparedness that universities should invest in teacher professional development for them to be updated about the paradigm shifts in the use of online technologies to offer effective and appropriate online teaching and assessments to students.

\section{References}

Anderson, T., Rourke, L., Garrison, D. R., \& Archer, W. (2001). Assessing teaching presence in a computer conferencing context. Journal of Asynchronous Learning Networks, 5(2), 1-17.

Bakia, M., Shear, L., Toyama, Y. \& Lasseter, A. (2012). Understanding the Implications of Online Learning for Educational Productivity (Report No. ED-01-CO-0040). U.S. Department of Education. http://www.ed.gov/technology

Bates, A. W. (2019). Teaching in a digital age. 2nd Edition. Vancouver: Tony Bates Associates. https://pressbooks.bccampus.ca/teachinginadigitalagev2/. Accessed 27 March 2021.

Bates, A. W. (2020). Advice to those about to teach online because of the corona-virus. 9 March. https://www.tonybates.ca/2020/03/09/advice-to-those-about-to-teach-online-because-of-the-corona-virus/Accessed 27 March 2021.

Carr-Chellman, A. (2016). Instructional design for teachers: improving classroom practice. $2^{\text {nd }}$ Edition. London: Routledge.

Ching, Y.-H., Hsu, Y.-C., \& Baldwin, S. (2018). Becoming an online teacher: an analysis of prospective online instructors' reflections. Journal of Interactive Learning Research, 29(2), 145-168.

Fawns, T. (2019). Postdigital education in design and practice. Postdigital Science and Education, 1(1), 132- 145. https://doi.org/10.1007/s42438-018-0021-8.

Garrison, D. R., Anderson, T., \& Archer, W. (2000). Critical inquiry in a text-based environment: Computer conferencing in higher education model. The Internet and Higher Education, 2(2-3), 87-105.

Goodyear, P., \& Dimitriadis, Y. (2013). In medias res: reframing design for learning. Research in Learning Technology, 21. https://journal.alt.ac.uk/index.php/rlt/article/view/1391. Accessed 27 March 2021. 
Hodges, C., Moore, S., Lockee, B., Trust, T., \& Bond, A. (2020). The difference between emergency remote teaching and online learning. Educause Review, 27March.https://er.educause.edu/articles/2020/3/the-difference-between-emergency-remote-teaching-and-onlinelearning. Accessed 27 March 2021.

Moallem, M. (1998). An expert teacher's thinking and teaching and instructional design models and principles: an ethnographic study. Educational Technology Research and Development, 46(2), 37-64. https://doi.org/10.1007/bf02299788.

Ocak, M. A. (2011). Why are faculty members not teaching blended courses? Insights from faculty members. Computers \& Education, 56(3), 689-699. https://doi.org/10.1016/j.compedu.2010.10.011.

Parchoma, G., Koole, M., Morrison, D., Nelson, D., \& Dreaver-Charles, K. (2019). Designing for learning in the yellow house: a comparison of instructional and learning design origins and practices. Higher Education Research \& Development, 1-16. https://doi.org/10.1080/07294360.2019.1704693.

Picciano, A. G. (2017). Theories and frameworks for online education: Seeking an integrated model. Online Learning, 21(3), 166-190.

Rahman, M., D., S. (2017). The Advantages and Disadvantages of Using Qualitative and Quantitative Approaches and Methods in Language "Testing and Assessment” Research: A Literature Review. Journal of Education and Learning, 6(1), 103-112.

Rapanta, C., Botturi, L., Goodyear, P., Guardia, L. \& Koole, M. (2020). Online University Teaching During and After the Covid-19 Crisis: Refocusing Teacher Presence and Learning Activity. Post digital Science and Education, 2, 923-945. https://doi.org/10.1007/s42438-02000155-y

Tennyson, R. D., \& Breuer, K. (2010). Psychological foundations for instructional design theory. In R. D. Tennyson, F. Schott, N. M. Seel, \& S. Dijkstra (Eds.), Instructional design international perspectives, Theory, research and models, Vol. 1 (pp. 113-134). New York: Routledge.

World Health Organization (n.d). Coronavirus disease (COVID-19) pandemic.https://www.who.int/emergencies/diseases/novelcoronavirus-2019 Accessed 27 March 2021. 